\title{
5. A TARDIA RESOLUÇÃO 02/87
}

\subsection{A tramitação inicial}

A proposta de minuta foi encaminhada ao MEC entre o final do ano de 1979 e o início do ano de 1980, e esperava-se que no ano seguinte já estivesse aprovado, publicado e implantado nas escolas (LONDON et al., 1979). No entanto, a tramitação do currículo não foi tão imediata quanto esperado. A presente pesquisa infelizmente não encontrou material suficiente para compreender a razão principal da demora na sua efetivação'.

Ao longo do primeiro quinquênio dos anos 1980, a categoria dos desenhistas industriais se manifestou algumas vezes em apoio à publicação do novo currículo, como nos ENDIs seguintes (1981, 1983 e 1985), e também no Encontro de Diretores de Escolas Superiores de Desenho Industrial do Brasil (1984). No entanto, tratam-se de notas de apoio, que não esclarecem qual a razão da demora para publicação.

Além de notas de apoio, começam a aparecer as primeiras críticas ao currículo definido no 1º ENDI. Em 1982, no Jornal da Apdins-RJ de no 6, Anamaria de Moraes faz uma crítica ao ensino oferecido nas escolas. Ela chama a atenção para

Quando em novembro de 2016 solicitou-se ao MEC informaçóes sobre o processo 563/81, do qual faz parte a Resolução no 2 - resolução que instituiu o novo Currículo Mínimo de desenho industrial -, o mesmo náo foi encontrado nos arquivos do Conselho Nacional de Educaçáo. 
alguns problemas internos estruturais de cada escola carioca ${ }^{2}$, e faz também uma série de comentários a respeito da importância da centralidade das disciplinas projetuais para a formação do desenhista industrial. Ao final de seu texto, a autora sugere como solução uma atualização do Currículo Mínimo do $1^{\circ}$ ENDI de 1979, no qual insere algumas novas matérias, todas ligadas ao ciclo de formação básica do aluno: Gerência de Produto (Controle e Cursos da Produção, Custo/Benefício e Custo/Efetividade, Mercadologia); Introdução à Projetação com auxílio de Computadores (Teoria de Sistemas, Modelagem, Linguagens Gráficas Computadorizadas); e Avaliação Social da Tecnologia (Ecologia, Impactos Culturais e Sociais, Seleção e Decisão) (MORAES, 1982). Essa é a primeira manifestação encontrada na presente pesquisa a tratar de uma atualização do Currículo Mínimo.

Nessa mesma edição do jornal, Joaquim Redig publica um texto intitulado "Ensino de Desenho Industrial", no qual, apesar de não citar especificamente o Currículo Mínimo, traz outros comentários interessantes às discussões sobre o ensino que se seguiriam nos anos seguintes. Nele ressalta a máxima importância do trabalho projetual prático para a formação do aluno. Ao tocar no papel do professor, Redig coloca:

Para uma escola ensinar pela prática,

é necessário que seus professores sejam praticantes dessa atividade, para que possam orientar seus alunos nesse sentido.

$A$ atividade prática na Escola

permite que seus professores ao mesmo tempo pratiquem e ensinem.

Os vinte anos de experiência brasileira no campo do Design

permitem que se utilize o conhecimento profissional para o ensino (REDIG, 1982)

No ano seguinte, em 1983, também num Jornal da Apdins-RJ, Bomfim apresentaria uma resposta aos textos de Redig e Moraes. No início de seu texto, afirma que a demora na aprovação de um currículo mínimo para o ensino é um problema importante, mas que questôes curriculares não são os únicos problemas do campo. Aponta um outro problema referente à quantidade de áreas que se consegue efeti-

A EBA estaria demasiado afetada por sua herança das Belas Artes, PUC demasiado influenciada por sua ideologia religiosa, e ESDI por sua aversão às questóes artísticas, padeceria de problemas quanto a disciplinas de representação de formas. 
vamente na atividade projetual, introduzindo assim a importância que teria uma especialização em áreas específicas do projeto.

Estamos acostumados à afirmação que o desenhista industrial é um profissional capaz de atuar em qualquer setor industrial: mobiliário, embalagens, eletrodomésticos, componentes para construção, equipamentos hospitalares, máquinas e implementos; enfim sobre toda produção material da sociedade.

[...] Nada mais mentiroso! Mas o horror que a palavra "especializaçâo" causa a professores e alunos dos cursos de desenho industrial é tamanho que preferimos continuar fazendo de conta que acreditamos na fábula do Designer-Faz-Tudo (BOMFIM, 1983)

Bomfim, quatro anos depois de sua participação na redação do Currículo Mínimo de 1979, questionaria a eficácia de um dos principais pontos, o da formação única, dividida posteriormente em duas habilitaçôes, alvo inclusive de debates entre as escolas. Importante ressaltar esse ponto de Bomfim pois, mais à frente, após a publicação do Currículo Mínimo em 1987, este assunto seria tratado nos debate sobre o ensino.

Quanto ao processo de aprovação do Currículo Mínimo, a única nota localizada a respeito do andamento do processo trata-se de um artigo de José Abramovitz, publicado no Jornal da Apdins-RJ, intitulado "Estão botando areia na proposta de Currículo Mínimo”. Lê-se:

O MEC não está reconhecendo as decisóes do $1^{\circ}$ ENDI. O Currículo Minimo elaborado pela Comissão Especial e depois discutido no ENDI e aprovado com as devidas modificaçóes não foi remetido pela SESU-Secretaria de Ensino Superior do MEC para o CFEConselho Federal de Educação.

Os membros que compuseram a Comissão Especial do MEC para elaborar o novo currículo, receberam uma carta da SESU agradecendo a participação e comunicando que o currículo seria novamente encaminhado às Escolas e (pasmem!) iria ser enviado para receber parecer da Comissão de Ensino de Engenharia e Arquitetura por ser um curso afim.

Na história da reformulação do Curriculo Minimo já foram feitas várias mesas redondas e compostas duas comissóes oficiais (uma antes do Seminário da ABENGE e outra tirada durante o Seminário, a qual trabalhou até o $1^{\circ}$ ENDI (ABRAMOVITZ, 1980). 
Ao longo deste capítulo, apresentam-se alguns eventos a princípio alheios ao Currículo Mínimo em si, mas que ao final provavelmente influenciaram sua aprovação em 1987. Ademais, apresentam algumas das dinâmicas de debates, as questôes em discussão, como estavam as escolas nos anos 1980 e as ideias que transitaram pela categoria ao longo deste período, que ajudam a entender porque já ocorrem críticas a esse Currículo Mínimo logo após sua aprovação

\subsection{Eventos do campo acadêmico do desenho industrial}

Os debates sobre questôes de ensino permaneceram acesos após o $1^{\circ}$ ENDI. Além dos ENDIs seguintes, em 1986 formou-se uma comissão pelo MEC para discutir os méritos do ensino brasileiro de design, e alguns dos contatos estabelecidos por este grupo fizeram com que o processo de publicação do Currículo Mínimo fosse retomado.

A decisão por constituir este grupo, entretanto, originou-se por influência de outros acontecimentos dos anos anteriores, conforme Eduardo Barroso relata em entrevista realizada em abril de 2017.

\subsubsection{Cadastramento Nacional de Desenhistas Industriais}

Para Barroso (BARROSO, 2017), um dos acontecimentos importantes para o processo, e que culminaria na criação da referida comissão pelo MEC, foi o Cadastramento Nacional de Desenhistas Industriais, ocorrido em 1983 por iniciativa de Barroso. Sua importância está, segundo ele, no fato de evidenciar em números a baixíssima absorção dos profissionais formados pelo mercado brasileiro, creditado entre outras coisas à baixa qualidade do ensino.

Ainda segundo o designer, o resultado do cadastramento seria uma das razóes que levaram à pesquisa de Geraldina Witter intitulada Desenho Industrial: Uma perspectiva educacional, publicada em 1985, também importante peça no debate do ensino de Desenho Industrial no período.

Tanto o cadastramento quanto a pesquisa de Witter resultam do papel de Barroso no CNPq. Em 1981, após retornar de seu mestrado na École Cantonal de Beaux-Arts et d'Art Appliqué de Lausanne, Eduardo Barroso publicou pelo Conselho Nacional de Desenvolvimento Científico e Tecnológico - CNPq o livro Estratégia de Design para os países periféricos, escrito na Suíça conjuntamente com Vanden Broeck e Thomas Kollbrunner (BARROSO, 2017).

Por causa desta publicação , Barroso ingressa no CNPq em 1982 para traba- 
lhar com Gui Bonsiepe no "Programa de Desenho Industrial" (BARROSO, 2017; LEON, 2013, p. 98). Até então, Barroso atuava no Centro Tecnológico de Minas Gerais - CETEC, onde entrou em 1973, quando cursava Artes Plásticas, mas atuava como designer, prática apreendida de maneira autodidata. Por influência de Radamés Teixeira, professor da Fuma, iniciou seus estudos na escola no curso de Desenho Industrial em 1974 (BARROSO, 2017).

Barroso afirma que a partir de seu envolvimento já dentro do CNPq com o III Plano Básico de Desenvolvimento Científico e Tecnológico PBDCT reconheceu que havia clara demanda do setor produtor nacional por desenhistas industriais, mas que tal demanda não estava sendo corretamente suprida por estes profissionais. Assim, organiza junto do $\mathrm{CNPq}$, em colaboração com as entidades de classe do NDI/CIESP, Apdins-RJ, Apdins-PE, ACVDI-MG e ADI-Santos, o Cadastramento Nacional de Desenhistas Industriais (BARROSO, 1984a).

Leon narra no início de seu livro Canasvieiras: um laboratório para o design brasileiro de onde surgiu o interesse de grupos dentro CNPq pelo desenho industrial, e o papel desempenhado por diversos agentes nas açóes engajadas pelo conselho. Diferentemente da frente de industrialização de Kubitschek, que era "[...] capitaneada pelas indústrias estrangeiras aqui implantadas, sobretudo as de bens de consumo duráveis" (LEON, 2014, p. 15), para parte dos governos militares consolidara-se "[...] a visão estratégica de desenvolvimento do país vinculado a questôes como segurança, soberania e desenvolvimento econômico” (LEON, 2014, p. 15). A pesquisadora destaca especificamente os governos Médici (1969-1974) e Geisel (1974-1979) como de maior desenvolvimento para as instituiçóes de pesquisa científica e tecnológica, e dentre elas, o CNPq.

Assim, no I PBDCT em 1973 estabeleceu-se um Programa de Desenho Industrial, criado efetivamente em 1975 sob coordenaçáo de Itiro Iida, tendo durado até 1977, quando trocou-se o ministro da Indústria e do Comércio (LEON, 2014, p. 22).

Em 1980, quando Lynaldo Cavalcanti de Albuquerque foi nomeado presidente do CNPq (LEON, 2014, p. 39), houve uma retomada do tema do Desenho Industrial dentro da instituição. Albuquerque fora reitor da UFPB, e durante seu mandato foi criado o curso de Desenho Industrial da universidade. Albuquerque tinha também bastante proximidade com Itiro Iida, a quem designou a criação do curso de Desenho Industrial em Campina Grande (LEON, 2014, p. 43). Iida ingressou no CNPq à época do III PBDCT, a convite de Albuquerque. 
Em 1981, Gui Bonsiepe foi convidado a ingressar no Conselho, quando buscava deixar a Argentina por conta da violenta ditadura que lá se instalara. Pouco depois, em 1983, seria fundado o Laboratório de Desenvolvimento de Produtos/ Desenho Industrial - LDP/DI, laboratório ligado ao CNPq sob a coordenação de Bonsiepe. O LDP/DI seria um importante centro de reciclagem e formação de docentes ao longo dos anos 1980 até os anos 1990. Segundo Iida (apud LEON, 2014, p. 60), o crescimento do número de escolas de Desenho Industrial nos anos 1980 era muito maior do que a possibilidade de preparação de professores, o que tendia a piorar a qualidade do ensino. Sem tempo hábil para a criação de programas de mestrado e doutorado, viu-se na criação do laboratório uma possibilidade de suprir essa necessidade.

Sendo este o contexto de interesse do CNPq no assunto do ensino e formação de desenhistas industriais, é nesse mesmo momento que se inicia o cadastramento, este sob os cuidados de Eduardo Barroso. O cadastro consistiu num trabalho de levantamento de dados quantitativos sobre os formados em Desenho Industrial no país em todas as dezoito escolas superiores de Desenho Industrial em funcionamento em 1983 - ano de realização da pesquisa -, a partir das listas de formados fornecidas pelas instituiçóes de ensino. Buscou-se dados de todos formados nos respectivos cursos desde suas inauguraçóes. Além dos dados cadastrais dos próprios designers, foram solicitadas também informaçóes de projetos realizados pelos mesmos, e também de experiências profissionais de seus autores desde graduados (BARROSO, 1984a).

Em depoimento, Barroso afirma que ao todo foram enviados mais de cinco mil questionários. Deste número, cadastraram-se ao final 1.219 profissionais - ou seja, perto de $30 \%$ do total formado no país desde 1963 -, e dados de 4.930 projetos realizados - dos quais apenas $20 \%$ chegaram a ser comercializados ${ }^{3}$ (BARROSO, 1984a). Não se obteve acesso ao questionário em si, mas parte dos resultados obtidos por Barroso encontram-se em palestra apresentada pelo designer em Seminário na Fundação Joaquim Nabuco, e também no $1^{\circ}$ Encontro dos Diretores das Escolas Superiores de Desenho Industrial, realizado em 1984.

No documento, Barroso inicia avaliando alguns dos problemas estruturais da industrialização nacional que levavam à baixa taxa de emprego dos designers, tais

Em seu depoimento, Barroso recorda-se que boa parte dos projetos incluídos nos questionários era de TCCs desenvolvidos ao longo da graduação dos respondentes, sendo este um dos pontos que justificariam esta baixa taxa de projetos comercializados. 
como políticas de desenvolvimento comprometidas com o capital internacional, “[...] favorecendo e estimulando a vinda de empresas multinacionais, sem uma política de apoio e proteção à pequena e média empresa brasileira [...] e sobretudo, sem uma política real de estímulo a inovaçáo tecnológica" (BARROSO, 1984a). Essa postura terminaria por incentivar as empresas a trazerem projetos já prontos de suas matrizes para serem apenas produzidos no Brasil.

A implicação disso na formação do desenhista industrial, ainda segundo Barroso, seria de exercerem atividades paralelas ao projeto de produto, ou de comunicação visual, tais como ilustração, propaganda, fotografia etc. E, mesmo entre os projetistas de produto, uma boa parte incluía a Comunicação Visual como uma de suas possíveis áreas de atuação (BARROSO, 1984a).

Este comportamento dos Desenhistas Industriais com o respaldo de alguns notáveis da época, provocam, ou ratificam, nas escolas um ensino da profissáo cada vez mais convergente ao "Design Superficial", a preocupação excessiva com os fatores estéticos, distanciando-se cada vez mais da indispensável competência tecnológica (BARROSO, 1984a)

Barroso ainda aponta outro "engano estratégico" (BARROSO, 1984a) da categoria quanto à ideia de convergência das duas carreiras de Desenho Gráfico e Desenho Industrial “[...] como meio de evitar a fragmentação em inúmeras especialidades de uma atividade emergente desprovida ainda de raízes, de amparo e de compreensão" (BARROSO, 1984a). Esse engano teria criado nos desenhistas industriais brasileiros uma "crise de identidade e uma crise de competência. [...] Dentro deste panorama, torna-se cada vez mais difícil esperarmos que os industriais compreendam nossa atividade" (BARROSO, 1984a).

Um último ponto levantado por Barroso é a respeito da "[...] inexistência de uma consciência de classe e a desarticulação da única entidade representativa então existente (ABDI)" (BARROSO, 1984a), que teria levado a uma oferta excessiva de profissionais formados num cenário de baixa absorção do setor produtivo.

Barroso apresenta duas sugestóes para aprofundar as discussôes de soluções a estes problemas:

A Qualquer processo de mudança é fruto de pressóes e esforços de determinado grupo de interesses, portanto vejo como absolutamente indispensável nossa rápida 
organização profissional, (representativa e atuante), brigando prioritariamente pela regulamentação da profissão, pelo estabelecimento de um piso salarial, pela aprovação do currículo minimo, e pela restrição a multiplicação de novas escolas. $B O$ redirecionamento das escolas para nossa realidade de mercado, buscando não só o incremento da capacitaçáo tecnológica dos graduados voltada ao atendimento das demandas regionais, bem como: tomando consciência de que o Desenho Industrial no Brasil (e sobretudo no Nordeste) não pode ser visto como uma atividade exclusiva do sistema produtivo (apesar de a este ser prioritariamente dirigido) devendo dar sua contribuição a construção de uma sociedade mais justa, projetando produtos e buscando soluçôes apropriadas as necessidades básicas da população de baixa renda (BARROSO, 1984a).

O documento termina anexando duas tabelas com a quantificação de alguns dos resultados do cadastramento, conforme a Tabela 13 e Tabela 14 a seguir.

\begin{tabular}{|c|c|c|c|c|c|}
\hline ESPECIALIDADE & TÉCN. & SUP. & MEST. & DOUT. & TOTAL \\
\hline Adaptação e Transferência de Tecnologia & 0 & 39 & 5 & 2 & 46 \\
\hline Assistência Téc. e Gerencial a Peq.Micro Emp. & 0 & 44 & 4 & 2 & 50 \\
\hline Avaliação Técnica e Ergonômica & 0 & 22 & 2 & o & 24 \\
\hline Bens de Capital & 0 & 4 & 1 & o & 5 \\
\hline Bens de Consumo em Geral & 0 & 31 & 3 & 3 & 37 \\
\hline Cálculo, Dimensionamento e Detalhamento de Prod. & 1 & 71 & 1 & o & 73 \\
\hline Design de Jóias & 0 & 27 & 0 & o & 27 \\
\hline Design Têxtil & 0 & 54 & 0 & $\mathbf{0}$ & 54 \\
\hline Eletrônica e Microeletrônica & 0 & 55 & 3 & 0 & 58 \\
\hline Embalagens & 0 & 169 & 5 & 0 & 174 \\
\hline Equipamentos Agrícolas & 0 & 13 & 4 & o & 17 \\
\hline Equipamentos Médico-Hospitalares & 0 & 21 & 4 & 0 & 25 \\
\hline Ergonomia & 0 & 60 & 8 & 3 & 71 \\
\hline Fashion Design/ Vestuário & 1 & 37 & 3 & o & 41 \\
\hline Furniture Design/ Móveis e Obj. de Decoração & 1 & 145 & 4 & 0 & 150 \\
\hline Graphic Design/ Comunicação Visual & 1 & 421 & 17 & 4 & 443 \\
\hline Instrumentos e Equip. Laboratoriais & 0 & 3 & 2 & 1 & 6 \\
\hline Maquetes e Construções de Modelos & 0 & 80 & 0 & o & 80 \\
\hline Rendering/ Téc. de Visualização & 0 & 14 & 0 & 0 & 14 \\
\hline Tecnologia Apropriada & 0 & 24 & 6 & 1 & 28 \\
\hline Teoria e Pesquisa do Design & 0 & 28 & 10 & 5 & 43 \\
\hline Transporte (Veículos e Equipamentos) & 0 & 50 & 2 & 1 & 53 \\
\hline
\end{tabular}




\begin{tabular}{llllll}
\hline ESPECIALIDADE & TÉCN. & SUP. & MEST. & DOUT. & TOTAL \\
Urban Design (Equip. Mobiliário Urbano) & 0 & 78 & 2 & 3 & 83 \\
\hline Desenvolvimentos de Produtos em Geral & 0 & 345 & 7 & 2 & 354 \\
\hline Áreas não especificadas anteriormente & 0 & 98 & 6 & 6 & 110 \\
\hline Não informado & 0 & 364 & 3 & 5 & 372 \\
\hline
\end{tabular}

Tabela 13: Número de profissionais cadastrados por especialidade. Fonte: BARROSO, $1984 a$.

\begin{tabular}{|c|c|c|c|c|c|c|c|c|}
\hline \multirow{2}{*}{$\begin{array}{l}\text { NÍVEL } \\
\text { ACADÊMICO }\end{array}$} & \multicolumn{4}{|c|}{ ANO DE CONCLUSÃO } & \multicolumn{2}{|c|}{ ATIVIDADE DOCENTE } & \multicolumn{2}{|c|}{ ATIVIDADE PROFISSIONAL } \\
\hline & 1981 & 1982 & 1983 & OUTROS & SIM & NÃO & SIM & NÃO \\
\hline Secundário & o & o & o & 2 & 1 & 1 & 2 & 0 \\
\hline Sup. Graduado & 111 & 157 & 307 & 572 & 247 & 900 & 902 & 245 \\
\hline Pós-Graduação & 5 & 5 & 6 & 35 & 32 & 19 & 38 & 13 \\
\hline Doutorado & 3 & 1 & o & 15 & 19 & 0 & 13 & 6 \\
\hline Pós-Doutorado & o & o & o & 0 & o & 0 & o & 0 \\
\hline Não informado & 0 & o & o & 0 & 0 & 0 & o & 0 \\
\hline Total & 119 & 163 & 313 & 624 & 299 & 920 & 955 & 264 \\
\hline
\end{tabular}

Tabela 14: Quantificação de profissionais por Nível de Formação/ Quantificação de docentes/ Quantificação de Empregados na profi ssão. Fonte: BARROSO, 1984a

Destes números, Barroso destaca o fato de, dentre os 1.219 cadastrados, 443 assinalarem exercer a Comunicação Visual como uma de suas especialidades (36.3\%). Segundo sua interpretação, isso se daria pelo fato de o designer procurar "[...] sobreviver como profissional, e na ausência quase total de um mercado para o desenvolvimento de novos produtos" (BARROSO, 1984a).

Destaca também o fato de 299 respondentes exercerem atividade docente (aproximadamente 25\%), que para Barroso indicaria a carência de professores altamente qualificados - já que destes apenas 51 possuíam pós-graduação -, e que essa alta taxa de 25\% transformava "[...] a escola no setor que mais absorve os profissionais da área, evidenciando um fenômeno quase autofágico” (BARROSO, 1984a). Não fica claro se esta pós-graduação refere-se a algum tipo de especialização, ao mestrado, ou a ambos.

A partir dos números do Quadro 1, não é possível inferir se os respondentes escolheram suas próprias áreas de atuação a partir de formulário de múltipla esco- 
lha, ou se a distribuição das respostas entre estes 25 itens partiu de classificação durante a própria da análise dos dados recebidos.

Caso tenha sido o primeiro caso, entende-se que foi possível aos respondentes selecionar mais de uma especialidade - há uma média de 2,5 especializaçóes por respondente (descontando do total de 1.219 o número referente a "Não informado"). E dentre as opçóes dadas, os dois itens com maior recorrência são justamente "Graphic Design/ Comunicação Visual" (36.3\%) e "Desenvolvimento de Produtos em Geral" (29\%), que são as habilitaçóes possibilitadas naquele momento segundo o Currículo Mínimo de 1969. Observa-se, ainda, que boa parte dos itens refere-se ao universo do design de objetos (adaptação de tecnologia, avaliação técnica e ergonômica, dimensionamento, joias, equipamentos agrícolas, médico-hospitalares etc.), o que elevaria a porcentagem de envolvidos nesta grande área do Projeto de Produto.

Ressalta-se isso pois, a partir dos dados tabelados acima - que são os únicos dados numéricos fornecidos no documento - e considerando a diferença percentual entre "Comunicaçáo Visual" e "Desenvolvimento de Produtos em Geral" ser de pouco mais de $7 \%$, não parece ser possível inferir que havia de fato um deslocamento maior à Comunicação Visual por falta de mercado para o Projeto de Produto. A conclusão de Barroso, se embasada de fato nos dados, tem de ter sido fundamentada pelas indicaçóes de projetos realizados por cada respondente, dados que não se teve acesso.

\subsubsection{Geraldina Witter: "Desenho Industrial: uma perspectiva educacional"}

Independente das ressalvas acima colocadas, a pesquisa realizada por Barroso teve como consequência importante, segundo seu depoimento (BARROSO, 2017) a realização de uma segunda pesquisa, encomendada ainda em 1983 pelo CNPq a pedido de Barroso, à pesquisadora Geraldina Porto Witter, que resultou na publicação Desenho Industrial: uma perspectiva educacional (WITTER, 1985). Colaboraram na publicação também Silvana Guimarães, Helena Bagnoli e Carla Witter.

\subsubsection{Motivações e intenções}

Segundo Barroso, a solicitação da pesquisa a Witter deu-se após o cadastramento identificar a baixa absorção de profissionais pelo mercado de trabalho, algo como um desdobramento daquele levantamento. Solicitou-se à pesquisadora “[...] 
visitar todas as escolas de Design do país, para entrevistar todos os professores que encontrassem... Professores, funcionários, alunos, ex-alunos, levantar os equipamentos, fotografar, fazer um dossiê de todas as escolas, de áreas, e durante um ano essas três pesquisadoras rodaram o país inteiro" (BARROSO, 2017).

Sobre o fato de nenhuma das pesquisadoras serem da área do design, mas sim de outras áreas diversas, Barroso coloca:

Nenhuma das três delas eram do campo do design, e o intuito era justamente esse. Um olhar critico, não emocional, com nenhum envolvimento, nenhum tipo de interesse. [...] Sabe, ela não sabia nem o que era design, teve que aprender o que era Desenho Industrial, Design. Teve que aprender sobre isso, não sabiam nada... $E$ eu acho que foi muito legal ter feito dessa forma, porque todas as leituras que a gente tem da questão do design no Brasil, tanto ensino quanto prática, 99\% foram escritas por designers. [...] E isso tem um viés que é complicado, porque a pessoa acaba puxando sardinha pro lado dela, pra regiáo dela (BARROSO, 2017)

Barroso ainda comenta que já conhecia Witter de outras pesquisas, e recomendou-a e às demais colaboradoras por causa de sua competência de pesquisa.

A pesquisa de Witter iniciou-se em 1983, e pretendeu:

[...] caracterizar o contexto histórico e as variáveis determinantes do desenvolvimento do Desenho Industrial e de seu ensino no Brasil; e estabelecer as bases para um modelo de análise da trajetória do Desenho Industrial no Brasil, detectando a influência da educação formal e não-formal, bem como do contexto histórico geral.

O primeiro destes objetivos compreende vários outros, mais específicos, implicando em:

analisar as ideias, os objetivos, as tecnologias que nortearam os primeiros grupos de profissionais, as primeiras escolas e as instituiçóes atualmente vigentes; detectar a contribuição do Desenho Industrial para o desenvolvimento sócio-econômico; analisar a assimilação do profissional pelo mercado de trabalho; analisar a integração escola-comunidade; analisar a formação e produção do corpo docente das escolas;

analisar o aproveitamento e a evasão escolar; $e$ 
traçar a história de cada escola de sua origem até o presente, focalizando os objetivos de ensino, os procedimentos, e tecnologias de ensino, o referencial técnico-prático, a grade curricular e os programas. (WITTER, 1985).

\subsection{3. $1^{\circ}$ Encontro dos Diretores de Escolas Superiores de Desenho Industrial do Brasil}

Eduardo Barroso, em sua entrevista, comentou que a partir dos achados do Cadastramento Nacional de Desenhistas Industriais organizou-se o $1^{\circ}$ Encontro dos Diretores de Escolas Superiores de Desenho Industrial do Brasil ${ }^{4}$, numa tentativa de achar uma saída aos problemas evidentes do ensino de Desenho Industrial no país. O local escolhido para o evento foi o Rio de Janeiro, em outubro de 1984, paralelo ao Congresso Latinoamericano de Desenho Industrial, da Associaçáo Latinoamericana de Desenho Industrial - a ALADI (BARROSO, 2017).

Em documento destinado à solicitação de verba do Fundo Nacional de Desenvolvimento da Educação, descrevem-se os objetivos do evento como:

a) avaliação do ensino de Desenho Industrial no Brasil, nos últimos 20 anos, e das dificuldades existentes à inserçâa da atividade no sistema produtivo;

b) proposição de métodos de ensino e de alternativas para a reciclagem de docentes; c) estabelecimento de graus de complexidade para as diferentes cadeiras de desenvolvimento de projetos (DEL FIACO, 1984)

O evento deveria incluir todas as 19 escolas superiores de Desenho Industrial do Brasil (BARROSO, 1984b). Boa parte dos documentos referentes ao evento encontra-se no acervo da Esdi, desde os pedidos de verba, passando pelas confirmaçôes individuais de cada uma das escolas para participação, até os anais do evento e materiais gráficos do mesmo.

Em 1982 aconteceu também um encontro entre as escolas do Rio de Janeiro, mencionado por Anamaria de Moraes no Jornal da Apdins-RJ de outubro de 1982, porém sem maiores detalhes. 


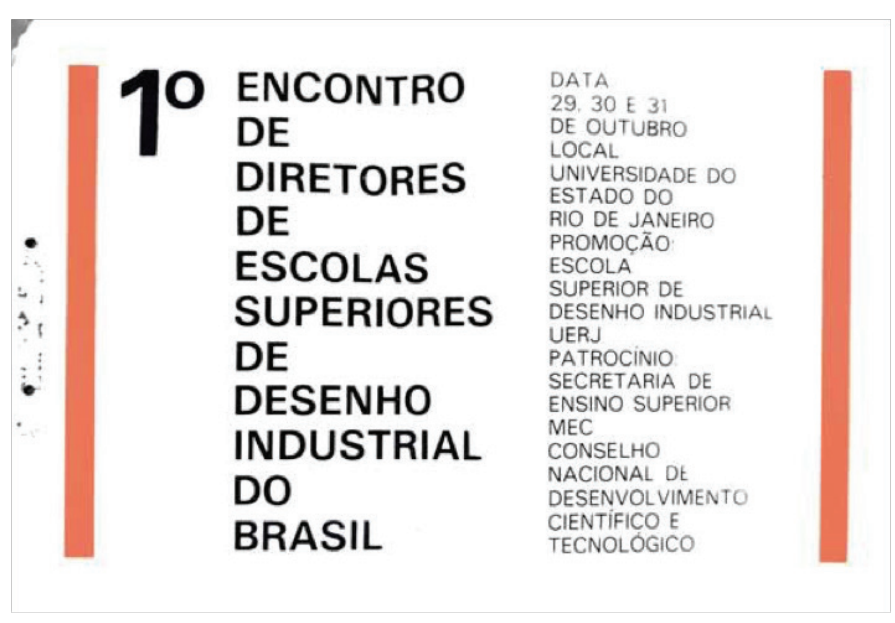

Figura 4: Cartaz de divulgação do $1^{\circ}$ Encontro de Diretores de Escolas Superiores de Desenho Industrial do Brasil - Formato A3.

Em resumo, o evento fez-se de palestra no primeiro horário da manhã, e grupos de discussão temáticos no meio da manhã e à tarde. Ao final do evento, redigiu-se um documento síntese.

O primeiro dia contou com a apresentação dos resultados do Cadastramento Nacional de Desenhistas Industriais por Eduardo Barroso, e também dos primeiros resultados da pesquisa feita por Geraldina Witter, para confirmação de dados pelos representantes das escolas.

Nos documentos distribuídos no evento consta a fala de Barroso anteriormente analisada, feita em seminário na Fundação Joaquim Nabuco. Constam também os currículos plenos das instituições Unesp, UFPA, UFPR (cursos de Comunicação Visual e Desenho Industrial), e UFMA.

Em documento contendo as consideraçôes finais tiradas do evento acusa-se a participação de treze escolas e universidades. Dentre as propostas apresentadas, o primeiro item refere-se ao Currículo Mínimo, onde escreve-se:

\section{Quanto à reformulação do Currículo Mínimo}

1. Envio de cartas ao CFE pedindo providências no sentido de aprovação do Currículo Minimo em tramitação desde 1979, assinada pelos representantes das Escolas presentes.

2. Solicitar ao SESU a constituição de uma comissão de Consultores na área de 
Desenho Industrial a partir de uma lista de especialistas escolhidos e indicados pelas Escolas de nivel superior.

3. Os diretores e Coordenadores presentes se comprometem a trabalhar no aprimoramento do currículo através do trabalho contínuo nas suas escolas, e levando os resultados a cada Encontro Regional ou Nacional.

4. Neste Encontro as Escolas ratificam e legitimam o trabalho que vem sendo desenvolvido pela Comissáo Nacional de Desenhistas Industriais criado no III ENDI com a finalidade de agilizar o processo de aprovação do CM junto ao CFE e a Regulamentação da Profissão junto ao Congresso Nacional.

5. As Escolas recomendam aos organizadores dos ENDI's, que incluam em todos os Encontros a discussão de questóes de ensino e atualização de currículo.

Estabeleceu-se a realização bianual deste mesmo encontro de diretores, que teria como pauta fixa a atualização do Currículo Mínimo, capacitação e aprimoramento de docentes e melhorias diversas no ensino. Como parte de um evento acadêmico com proposiçôes práticas à categoria, esta é a primeira menção documental específica a tratar de alguma atualização ao Currículo Mínimo desde seu envio ao MEC5.

Pautas variáveis deveriam ser abordadas nos encontros regionais das escolas, divididos por estados. Um primeiro grupo, composto por São Paulo, Paraná e Santa Catarina, aconteceria na Faap. Um segundo grupo, composto por Rio de Janeiro e Minas Gerais, aconteceria na FAC 6 , e um terceiro grupo, composto por Pernambuco, Maranhão e Paraíba, aconteceria na UFPE.

Destes, sabe-se ao menos dos encontros que aconteceram na Faap, e na UFPE. Este último, denominado $1^{\circ}$ Encontro Regional de Escolas de Desenho Industrial/ Nordeste $^{7}$, aconteceu de 16 a 19 de setembro de 1985.

Além de todos os pontos anteriores, comentou-se ainda da formação de uma

Como colocado no início deste capítulo, há uma menção individual de Anamaria de Moraes sugerindo atualizaçóes ao currículo, publicada no Jornal da Apdins-RJ em 1982, mas esta refere-se à análise pessoal da pesquisadora, e não de um grupo representativo (MORAES, 1982).

6 A sigla não é extendida no documento, mas possivelmente trata-se da Faculdade da Cidade, que funcionava na cidade do Rio de Janeiro.

Apesar do evento identificar-se como "1o Encontro...", no início de 1979 aconteceu outro evento semelhante, denominado "Primeiro Encontro das Escolas de Desenho Industrial do Nordeste", patrocinado pelos cursos da UFPE e UFPB. 
comissão que estudaria a criação da Associação Brasileira das Entidades de Ensino de Desenho Industrial - ABEDI. Chegou-se efetivamente a elaborar uma proposta de estatuto para a associação (ABEDI, 1985), que foi apresentada no encontro regional do Nordeste, em 1985.

Ressalta-se a importância desse movimento por tratar-se de uma primeira tentativa de fato concreta de fundar uma instituição dedicada à discussão do ensino e representação das escolas. A ABEDI não se efetivaria ao final, mas mostra-se um importante indicativo de um processo de amadurecimento da categoria acadêmica do Desenho Industrial que culminaria em 1988 na fundação da Associação de Ensino de Design do Brasil - AEnD-BR, entidade que mais tarde em conjunto com os editores da revista Estudos em Design iniciaria o P\&D Design, primeiro congresso dedicado à pesquisa do design.

A diferente nomenclatura de ambas associaçóes pode, talvez, denotar diferentes abordagens ao problema de representatividade no ensino. A primeira, ABEDI, explicita sua relação com as Entidades de Ensino, enquanto a segunda, AEnD-BR, é mais abrangente em seu espectro ao tratar do ensino em aspectos gerais e para além das escolas. Dado que a proposta da ABEDI saiu justamente de um encontro de diretores de escolas, faz sentido que se pretendesse representar instituiçóes.

Tanto o Cadastramento Nacional de Desenhistas Industriais, quanto a publicação de Geraldina Witter, e também o $1^{\circ}$ Encontro de Diretores de Escolas Superiores de Desenho Industrial do Brasil foram, ao final, iniciativas coordenadas pelo $\mathrm{CNPq}$ - apenas neste último caso, em conjunto com a SESu MEC. Barroso, em seu depoimento, coloca que isso limitava a influência que o evento poderia ter no andamento do Currículo Mínimo, já que o CNPq pertencia ao Ministério da Ciência e Tecnologia, enquanto o ensino é atribuição do Ministério da Educação. Afirma, então, que enviou uma carta ao MEC, afirmando a urgência e necessidade de dar andamento ao processo do Currículo Mínimo (BARROSO, 2017). No entanto, no resumo do encontro de diretores, fica clara a decisão da plenária também pela redação e encaminhamento de uma correspondência com o mesmo intuito, mas assinada por todos as escolas presentes.

\subsubsection{Comissão para Avaliação do Ensino Superior de Desenho Industrial}

Não se sabe, ao final, se tratou-se de uma carta conjunta, ou se foi enviada apenas pelo próprio Eduardo Barroso. Mas em 02 de junho de 1986 o MEC de fato monta um Grupo de Trabalho com a finalidade de "[...] avaliar o ensino supe- 
rior de Desenho Industrial” (MENEZES NETO, 1986).

Designou-se por meio de publicação no Diário Oficial da União como membros da comissão Jorge Hans Max Bonsiepe (Gui Bonsiepe - UFSC), Eduardo Barroso Neto (CNPq), Antonio Carlos Ramirez Righi (UFPE), João Roberto Costa do Nascimento (CNDI), Joaquim de Salles Redig de Campos (Esdi), e Olício Carlos Pelosi (Unesp). Não se explicam os motivos por trás dessas escolhas, mas observa-se a presença de três escolas públicas de diferentes estados, além da presença do CNDI - Comissáo Nacional de Desenho Industrial, criada no $2^{\circ}$ ENDI, que ficou responsável pelo acompanhamento do processo de regulamentaçáo da profissão em Brasília. Gui Bonsiepe, apesar de identificado como UFSC, não atuava como docente, mas sim como pesquisador no Laboratório Brasileiro de Desenho Industrial - LBDI.

Estabeleceu-se ao grupo o prazo de noventa dias para a realização dos trabalhos, a redação de um relatório que fizesse uma avaliação crítica do ensino superior de Desenho Industrial, e também a formulação de recomendaçóes para a melhoria do ensino.

Em release divulgado por Barroso, conjuntamente de uma carta datada de 05 de junho de 1986 às associaçóes da categoria informando sobre a constituição do grupo de trabalho, fala-se da realização de uma atividade junto ao presidente do CFE, Dr. Fernando Gay da Fonseca, quando se obteve "[...] a promessa de agilizar a análise do currículo mínimo para os cursos de Desenho Industrial, em tramitação desde 1980, sendo este o primeiro passo para a melhoria do ensino" (BARROSO, 1986a).

Em seu cronograma de trabalho (BARROSO, 1986b), tirado em reuniôes nos dias 04 e 05 de junho de 1986, aponta-se que no mesmo dia 05 de junho, o grupo reuniu-se com Dr. Fernando Gay da Fonseca e também com o Conselheiro Jucundino Furtado, responsável pela análise da proposta de Currículo Mínimo enviada em 1979. Determinou-se o prazo de 30 dias para a elaboração de seu parecer, bem como a desvinculação do processo de análise do Currículo Mínimo de Arquitetura.

Cada membro do grupo deveria, após esta reunião, contatar as instituições de ensino de sua região para colher críticas e sugestóes. A divisão das escolas ficou da seguinte maneira (BARROSO, 1986b):

G. Bonsiepe: PUC/RS; UFPR; PUC/PR; UFSC e Sta.Maria/RS 
Olício Pelosi: FAAP; Mackenzie; FAUUSP; FEB; Mauá; Sta Cecília; Sm Marcelina; UNIFRAN; Farias Brito

J. Redig: ESDI; UFRJ; Silva e Souza; CIDADE; PUC/CI

E. Barroso: FUMA/MG

C. Righi: UFPE/UFMA/UFPB/ UFRN/ UNEB

J. Roberto: Associaçôes Profissionais (APDIMG; APDI-PE; APDINS-RJ; APDINS-PR; ALADI) (BARROSO, 19866)

Destacamos a presença da Fauusp como instituição a ser consultada, apesar de ainda não possuir curso de Desenho Industrial; e também a consulta às associaçôes, dentre elas a ALADI - Associação Latino Americana de Desenho Industrial.

Cada membro deveria formular, em seguida, um relatório "[...] contendo problemas e sugestôes para cada um dos sub-temas abaixo listados" (BARROSO, 1986b):

6.2.1. Aspectos conceituais do Desenho Industrial

6.2.2. Curriculum (Minimo e Pleno)

6.2.3. Infraestrutura Acadêmica

6.2.4. Processos de seleção e avaliação de alunos

6.2.5. Capacitação de docentes

6.2.6. Informação Técnica

6.2.7. Sistemas de avaliaçâo do desempenho acadêmico

6.2.8. Formas alternativas e opcionais para aumento da capacitaçáo docentel discente

6.2.9. Representação junto aos órgãos de governo

6.2.10. Aspectos administrativos e financeiros

6.2.11. Aspectos institucionais/ vinculação departamental

6.2.12. Pós-Graduação em Desenho Industrial

6.2.13. Processos de acompanhamento e avaliação

6.2.14. Recomendaçóes finais (BARROSO, 1986b) 
Nos dias 10 e 11 de junho ${ }^{8}$, uma nova reunião no Rio de Janeiro deveria ser usada para confronto das informaçôes, com data prevista para consolidação final até o dia 02 de setembro, para serem entregues à SESu/MEC.

\subsubsection{Relatório parcial, e Seminários das Escolas}

Em 24 de junho de 1986, João Roberto Costa do Nascimento (Peixe) enviou uma carta a Lia Mônica Rossi, professora na UFPB e representante regional do CNDI na Paraíba, informando sobre a continuidade dos trabalhos desse grupo. Nela, refere-se a uma circular enviada a várias escolas e pessoas sobre a realização de debates e seminários, que deveriam gerar relatórios a serem encaminhados ao Grupo de Trabalho, dando prazo de trinta dias para o envio dos mesmos.

Em anexo à correspondência segue um modelo de telegrama que deveria ser enviado pelas entidades e instituiçóes aos contatos indicados. Segue o conteúdo indicado:

[Destinatário] Dr. Fernando Gay da Fonseca [...]

PROTESTAMO NÁO CUMPRIMENTO COMPROMISSO ASSUMIDO CONSELHEIRO JUCUNDINO SILVA FURTADO, REUNIÃO 05 JUNHO 1986 ENTREGA PARECER CURRÍCULO MÍNIMO DESENHO INDUSTRIAL INÍCIO MÊS JULHO AO COORDENADOR GRUPO ENSINO SESUIMINISTÉRIO EDUCAÇÃO EDUARDO BARROSO. EXIGIMOS PROVIDENCIAS IMEDIATAS FACE PROTELAÇÃO 6 ANOS PROCESSO $(s / n, 1986)$

Observa-se que a data referida para publicação pelo conselheiro Jucundino

As datas entre os documentos tornam o entendimento do processo como um todo um pouco confuso. Apesar de afirmar-se que a próxima reunião deveria ser nos dias 10 e 11 de junho, afirma-se também que após a reuniáo do dia 05 de junho cada membro teria 30 dias para redação de seu relatório sobre as instituiçóes pelas quais se responsabilizaram, o que implicaria que as datas desta próxima reuniáo fosse algo após 05 de julho - talvez 10 e 11 de julho -, caracterizando, assim, um erro de escrita. No entanto, um primeiro relatório dos trabalhos do grupo já se encontrava pronto e fora enviado às escolas no dia 26 de junho - anterior ao prazo estimado dos relatórios com as instituiçóes -, com prazo de comentários para até 30 dias, ou seja, final de julho, conforme colocado a seguir. Assim, a menos que tal relatório tenha sido escrito sem os relatórios sobre as instituiçôes, devem ter havido alteraçóes de datas e prazos deste cronograma inicial durante o processo. 
Silva Furtado seria do início de julho de 1986, ainda dentro do prazo de noventa dias para os trabalhos da comissão. Isso é importante de ser observado por indicar que o papel da comissão de avaliaçáo do ensino superior de Desenho Industrial não focou em uma rediscussão da proposta de Currículo Mínimo tirada no $1^{\circ}$ ENDI, dado que as pressóes para publicação urgente do Currículo Mínimo seguiam paralelas aos esforços do grupo.

Quanto aos referidos seminários, foi enviada às escolas uma versão preliminar do relatório do grupo de trabalho. Seguiu a mesma estrutura de pontos estipulados na reunião do dia 05 de junho de 1986.

No primeiro ponto tratam da nomenclatura da profissão. Observou-se que o termo "desenho", que normalmente combinava-se com adjetivos especificadores para tratar de atividades de representação e reproduções gráficas, acabava por trazer problemas para designar uma atividade projetual complexa e abrangente. A sugestão do grupo, entretanto, não é a de mudança de nomenclatura, mas sim de tentativa de restrição ainda maior do uso de "desenho industrial", para que em algum momento pudesse se referir apenas à profissão. Desencoraja-se, assim, que se use tal nome em cursos técnicos ou de licenciatura. Comparam, para este fim, à área da engenharia:

Tal como não existe um "desenhista em engenharia mecânica", porém sim um "desenhista mecânico", o Grupo aconselha não oficializar o termo "técnico em desenho industrial" ou "desenhista industrial de nivel técnico". Da mesma forma como não existe "licenciado em arquitetura", não deve existir "licenciado em desenho industrial" (BARROSO et al, 1986)

O segundo ponto refere-se aos currículos, mínimo e pleno. Iniciam por ratificar a proposta de Currículo Mínimo já encaminhada ao MEC em 1980, e reforçam que outros eventos já tinham também ratificado esta mesma proposta (20 ENDI 1981, 3 ENDI 1983, 4º ENDI 1985, e também o 1º Encontro de Diretores de Escolas Superiores de Desenho Industrial do Brasil). Afirmam, também, que a proposta enviada encontrava-se de posse do conselheiro Jucundino Furtado desde o momento de envio, após o $1^{\circ}$ ENDI, e que seu andamento deveria ser desvinculado do andamento do Currículo Mínimo de Arquitetura - dado sobre o qual não foram encontradas maiores informaçóes ao longo desta pesquisa.

No entanto, apesar de ratificarem sua aprovaçáo, o grupo sugere alguns aden- 
dos, conforme segue:

2.2. Recomendamos que as Escolas sejam instruidas no sentido de ministrar as disciplinas projetuais do primeiro ao último ano [...].

2.3. Recomenda-se ainda que estas disciplinas de projeto sejam ministradas em blocos de 3 a 4 horas/dia [...].

2.4. A carga horária do conjunto das disciplinas de projeto não deverá ser inferior a 50\% do currículo minimo, correspondendo a 1.600 horas/aula (recomendação do ICSID/ UNESCO).

2.5. As disciplinas teóricas deverão ocupar $30 \%$ do tempo do currículo minimo, e as disciplinas técnicas (práticas) 20\% [...].

2.6. Para a formação das turmas de disciplinas projetuais, em qualquer periodo do curso, deve-se manter uma relação professor/ aluno de no máximo 1/15 [...].

2.7. As disciplinas de projeto deverão se interrelacionar com outras disciplinas ministradas [...]

2.8. As demais disciplinas (teóricas ou técnicas) devem ser orientadas para o design (integração entre teoria e prática) e sequenciadas de forma orgânica (BARROSO et al, 1986)

É interessante de se observar que se tratam de algumas das consideraçôes colocadas pela PUC-RJ quando se avaliou o currículo proposto pela primeira comissão formada pelo MEC em abril de 1978. Naquele momento, comentou-se sobre a proporção de matérias projetuais, e também que os conteúdos teóricos deveriam ser, explicitamente, alinhados a conteúdos de projeto (ESCOREL et al., 1978).

$\mathrm{O}$ terceiro ponto apresentado no relatório refere-se à infraestrutura das escolas, sugerindo que todo curso de Desenho Industrial estivesse munido de uma Sala de Desenho para aulas práticas, e oficinas de apoio às matérias de projeto e práticas, com técnicos especialistas (madeira, metal, gesso, papel e equipamentos para impressão e reprodução gráfica, serigrafia, estúdios e laboratório fotográfico). Sugerem como conveniente, ainda, que houvesse equipamentos para vídeos, computação gráfica e sistemas CAD.

O quarto ponto refere-se ao processo seletivo e avaliaçáo dos alunos. Recomendam a adoção de exames específicos para Desenho Industrial, "[...] evitando o ingresso de pessoas não interessadas" (BARROSO et al., 1986), e recordam de 
proposta colocada no $4^{\circ}$ ENDI para elaboração de vestibular para os cursos. Tal proposta, entretanto, não consta nos anais do evento, em sua sessão dedicada ao ensino.

Sobre a avaliação e progressão do aluno nos cursos, sugerem a extinção do sistema de créditos, que "[...] leva a desagregação do corpo docente e sobretudo do discente" (BARROSO et al., 1986), e adoção de uma avaliação por períodos. Proposta semelhante foi colocada por Décio Pignatari em seu manifesto sobre um Ensino Automático, no $1^{\circ}$ Seminário de Ensino de Desenho Industrial, em 1965, mais de vinte anos antes do documento (PIGNATARI, 1965).

Ainda neste mesmo item, o relatório recomenda que sejam exigidos projetos de conclusão de curso para todos os alunos, e há referência explícita à realização de projetos com o objetivo de "[...] verificar sua maturidade na área projetual, e sua concepção do D.I." (BARROSO et al., 1986), sem comentários sobre a possibilidade de trabalhos teóricos, que já eram praticados na Esdi ao longo dos anos 1970 (SOUZA, 1996).

O quinto ponto do relatório refere-se à capacitação de docentes:

O Sistema atual de qualificação acadêmica, com seus títulos correspondentes (mestrado, doutorado), está estruturado segundo as necessidades e critérios das ciências básicas.

Este modelo não se adapta às necessidades da área de projeto sendo mais relevante no caso a experiência profissional dos docentes.

Recomenda-se, para a seleção (concursos) e a ascensão do docente da área projetual na carreira acadêmica, a adoção de um plano de equivalência, onde a experiência profissional corresponda às titulaçôes de mestrado e doutorado [...].

Recomenda-se ainda que as Instituiçóes de Ensino não só estimulem como exijam a atividade profissional dos docentes da área projetual, dentro ou fora da Instituição, como forma de possibilitar sua capacitação contínua para o ensino nessa área (BARROSO et al, 1986).

Observa-se neste trecho uma recomendação explícita apenas a docentes de disciplinas projetuais. Para matérias técnicas e teóricas, não há referência clara sobre a maneira de qualificação do docente, portanto, entende-se que para estes casos os títulos acadêmicos normais (mestrado e doutorado) estariam ainda válidos. 
Há certa insistência no relatório em tratar da formação projetual do docente, o que revela uma profunda preocupaçáo com professores que ingressam na escola logo após formados, sem efetiva vivência profissional como projetista. Tal preocupaçáo transparece também no item seguinte do relatório:

Recomenda-se que o MEC [...] incentive e apoie a adoção, pelas escolas interessadas, do experimento em curso na UFPE, que institue o período de formação complementar de um ano, onde os recém graduados desenvolvem, com orientação, supervisão e apoio institucional e docente, projetos contratados junto a indústrias ou empresas públicas e privadas.

Essa atividade, assemelhada em parte ao regime de residência adotado na área médica, objetiva aumentar a capacidade, maturidade e segurança projetual do formado, bom [SIC] como possibilitar ao docente-orientador maior experiência com projetos e necessidades reais (BARROSO et al, 1986)

Embora Barroso, em sua análise sobre o Cadastramento de Profissionais de Desenho Industrial, não comente explicitamente sobre professores recém-formados, ele o faz de maneira implícita ao falar sobre certa "autofagia" que identificava no fato da escola ser o maior captador de mão de obra dos profissionais (BARROSO, 1984a).

Recorda-se aqui, que Redig já havia manifestado sua opinião em 1982 sobre a importância da prática projetual do professor para o sucesso do ensino de projeto (REDIG, 1982). Intui-se, por essa razão, que tenha sido o próprio Redig quem introduziu tal questão no grupo da comissão, resultando na inclusão desta proposta.

Quanto à proposta de seguir o modelo da UFPE de período complementar após a graduação, recorda-se que um dos membros do grupo, Carlos Antônio Ramirez Righi, lecionava na UFPE desde 1983, e é provavelmente o mentor da proposta neste grupo.

O restante do relatório refere-se a aspectos administrativos, financeiros e institucionais das escolas e da categoria junto o MEC. Entre essas recomenda-se repetidamente a criação de uma comissão permanente de Desenho Industrial junto ao MEC (BARROSO et al., 1986).

Conforme documentos encontrados no acervo de Lia Monica Rossi, tanto a UFPE quanto a UFPB realizaram ediçôes dos seminários solicitados pelo grupo, 
para estudo e comentários sobre o relatório, mas não há notícias de outras instituiçóes que o tenha feito ${ }^{9}$. Destas duas, teve-se acesso aos comentários efetuados pela UFPB.

O primeiro comentário, sobre "aspectos conceituais do desenho industrial", advoga que a responsabilidade de fiscalizar e impedir o uso do termo Desenho Industrial em cursos técnicos e licenciaturas deve ser do CFE e da comissão permanente que lá se instalaria. Também havia um alerta para o caso particular da FAU/ USP:

Em relação à habilitação para o exercício da profissão, esta deverá ser regida pela regulamentação da profissão. Até lá arquitetos formados pela FAU/USP, por exemplo, seguirão se sentindo no direito de exercer a profissáo a partir de algumas disciplinas do D.I. cursadas durante a graduação em arquitetura (MACEDO e ROSSI, 1986)

Sobre o segundo ponto, dos currículos mínimo e pleno, afirma-se que representante do $\mathrm{CNDI} / \mathrm{PB}$ enviou o referido telegrama, conforme solicitado.

Quanto à recomendação de se seguir o modelo ICSID/UNESCO, afirmam que:

O modêlo ICSID/UNESCO nos parece incompativel com o que vem sendo discutido e proposto nestes últimos anos no Brasil e na América Latina sobre o papel do D.I. O modêlo citado tente à formação de técnicos e não à geraçấo de pessoas críticas e capazes de identificar as necessidades reais da populaçâo e participar na resolução de problemas dentro do processo de inovação tecnológica. Como se sabe são as disciplinas teóricas, sobretudo da área de humanidades, as que melhor propiciam elementos de formaçâo crítica ao alunado.

O curso de D.I. da UFPb trabalha com 540 horas na Matéria Projeto. Ainda que se aumente a carga horária semestral de 60 para

90 horas (3 horas-aula por dia) teríamos 810 horas de Projeto durante o Curso, ou seja, 790 horas a menos que o recomenda do pelo ICSID/UNESCO. Esta re-

Aqui os dados encontrados são de fato parciais, dado que o acervo de Lia Monica Rossi possui especificamente materiais de universidades do Nordeste do Brasil. Assim, nesse caso é bastante importante ressaltar que o desconhecimento de outras ediçóes do seminário não implica que estes não tenham acontecido. Trata-se provavelmente de um problema de acesso à documentação. 
comendação (1.600 horas) exigiria 3-horas-aula durante 4 dias úteis!!

Pergunta-se: QUAL O NOSSO MODELLO? QUAL O NOSSO MARCO DE REFERENCIA? QUAIS OS NOSSOS OBJETIVOS? (MACEDO e ROSSI, 1986)

A respeito dos processos de avaliação e seleção, mostram-se favoráveis tanto a um vestibular específico para Desenho Industrial, como à extinção dos sistemas de crédito em prol de uma flexibilidade por períodos de aprendizagem.

Já sobre a capacitação docente, discordam da necessidade do professor atuar profissionalmente. "Não vemos como 'exigir' a atividade profissional dos docentes no âmbito projetual uma vez que há diferenças e restriçóes contratuais entre IES” (MACEDO e ROSSI, 1986).

É interessante observar que o argumento contrário à exigência tem certo caráter "legalista", mas aceita-se o ponto da extinção do sistema de créditos, que implicaria igual reavaliação da legislação por parte do MEC ou dos órgãos responsáveis. Seriam necessários mais dados para uma análise mais aprofundada a respeito disso, mas observa-se aqui um conflito interno do campo acadêmico do Desenho Industrial, sobre a capacidade ou não do docente de ensinar projeto adequadamente sem uma vivência ativa da sua prática, sendo o argumento de Macedo e Rossi favorável à certa flexibilização neste ponto, enquanto a comissão, e especialmente Redig, seriam outras vozes deste debate. Seguindo a pesquisa de Barroso, segundo a qual uma boa parte dos formados encontra no ensino seu "mercado de trabalho", defender tal flexibilização seria, ao final, garantir campo de atuação ao formado, que poderia encontrar dificuldades num mercado profissional saturado e pouco desenvolvido.

\subsubsection{Relatório final da Comissão}

A última reunião do Grupo de Trabalho sobre o Ensino de Desenho Industrial deu-se nos dias 01 e 02 de setembro de 1986, em Brasília (NASCIMENTO, 1986), conforme previsto no cronograma do grupo (BARROSO, 1986b). Nesta reunião, foi entregue o relatório final do grupo ao secretário do SESu/ MEC, Prof. Paulo Eupídio de Menezes Neto, que teria se comprometido a estudá-lo, e agilizar tanto a aprovação do Currículo Mínimo quanto a criação da solicitada Comissão Permanente de Ensino.

A análise do Currículo Mínimo, afirma-se no documento (NASCIMENTO, 
1986), teria passado das mãos do conselheiro Jucundino da Silva Furtado para ser responsabilidade de Rui Vieira. Este foi um dos principais contatos do CFE e da categoria nos anos de 1978 e 1979, tendo supervisionado a redação da primeira proposta de Currículo Mínimo em abril de 1978, seguido pela realização do Seminário "Desenho Industrial e Ensino" - do qual fez parte -, e a subsequente Comissão Especial de Desenho Industrial, até o 1o ENDI em 1979.

O Prof. Rui Vieira, juntamente com o Itiro Iida, tiveram uma reunião com o Grupo de Trabalho, e comprometeram-se em, imediatamente, prepararem o parecer favorável à sua aprovação, e enviá-lo ao Conselho do CFE, para, na sua próxima reunião, ser submetida à apreciação dos Conselheiros. Estamos aguardando a sua aprovação pelo CFE, agora, com grande otimismo (NASCIMENTO, 1986).

- No primeiro item, sobre a denominação "Desenhista Industrial”, removeu-se a explicação sobre as confusóes que o nome remete ("desenho" como representação vs atividade projetiva), focando no reforço sobre a aprovação do projeto de lei que regulamentaria a profissão, e da proibição que o nome fosse usado em cursos técnicos e de licenciatura. Acrescentou-se, ainda, que a inserção de matérias denominadas "Desenho Industrial" eram estimuladas em áreas próximas, tais como Engenharia e Arquitetura, mas apenas como matéria de "domínio conexo, como complementação curricular" (BARROSO et al, 1986c), e não como uma forma de habilitar os estudantes destes outros cursos à prática profissional do Desenho Industrial.

- Sobre o assunto do Currículo, ratifica-se o apoio à publicação do Currículo Mínimo em análise pelo CFE. Os adendos da versão anterior permanecem, mas, seguindo a sugestão colocada pela UFPb, não há mais a recomendação de carga horária mínima de 1600 horas de projeto, conforme sugerido pelo ICSID/UNESCO.

- Para aspectos de Infraestrutura, permanecem todas as recomendaçóes.

- Sobre Aspectos Institucionais de seleção e avaliação de alunos, removeu-se o conteúdo inicial sobre exames vestibulares específicos, bem como as observações a contra o sistema de créditos.

- No lugar, recomenda-se desvincular os cursos de Desenho Industrial das licenciaturas em desenho ou arte, e também de departamentos de arquitetura e 
engenharia. "Estas recomendaçôes partem do princípio de que o D.I. não cabe exclusivamente em nenhuma área do conhecimento clássico (artes, ciências sociais, tecnologia), e que a indefinição da vinculação acadêmica [...] tem colaborado para ampliar as dúvidas quando à função profissional do Desenhista Industrial" (BARROSO et al, 1986 c).

- Sobre Avaliação Docente, retirou-se a obrigatoriedade de experiência profissional em projetos, mas se a manteve como sugestão, pela "[...] valorização da experiência profissional em níveis equivalentes às titulaçóes de mestrado e doutorado" (BARROSO et al, 1986c).

- Foi mantida também a sugestão de programas semelhantes ao da Ufpe, de um período de formação complementar de um ano, para desenvolvimento de projetos supervisionados junto a indústrias ou empresas.

\subsection{Parecer 62/87 de J. Furtado e a Resolução 02/87 publicada no DOU}

Apesar de o informativo de Nascimento (1986) apontar Rui Camargo Vieira como novo responsável pelo andamento do processo do Currículo Mínimo, quem assina o relatório do parecer 62/87 foi o próprio conselheiro Jucundino da Silva Furtado, responsável desde o início da análise do documento. O documento possui data de aprovação em 29 de janeiro de 1987, e data de redação de 8 de outubro de 1986, pouco mais de um mês após a entrega final do relatório do Grupo de Trabalho sobre Ensino de Desenho Industrial.

\subsubsection{O relatório do Parecer 62/87}

No início do relatório, Furtado traça a sequência de fatos desde certa etapa de início do processo de reformulação do currículo, até aquele momento. Além disso, o relator informa sobre a mudança de dois cursos diversos, um de Desenho Industrial e outro de Comunicação Visual, conforme se apresentava na resolução no $05 / 69$, para uma nova configuração, sendo Desenho Industrial como curso, e duas habilitaçôes possíveis, de Projeto de Produto, e Programação Visual - não mais Comunicação Visual (FURTADO, 1987).

Observa-se, nesse sentido, que a experiência acumulada no decorrer de quase vinte anos contribuiu para a sedimentação dos conceitos, muitas vezes controvertidos, de tal forma que a alteraçâo das denominaçóes anteriormente aceitas para os dois 
cursos passou a encontrar plena justificativa. De fato, desde o início do primeiro curso de Desenho Industrial entre nós, na Escola Superior de Desenho Industrial, no Rio de Janeiro, em 1962, foram se consolidando as conceituaçóes e convergindo as opinióes para uma concepção mais homogênea das atividades profissionais desenvolvidas no âmbito dessa importante área (FURTADO, 1987)

Furtado reconhece 1978 como momento inicial do processo de elaboração do novo currículo. Coloca que

[...] já em 1978, por iniciativa do antigo Departamento de Assuntos Universitários do MEC, foi composto um grupo de trabalho que elaborou uma proposta preliminar de novos currículos minimos, que foi em seguida apreciada por todas as instituiçôes acadêmicas e profissionais de Desenho Industrial em Seminário realizado em Sáo Paulo sobre "Desenho Industrial e o Ensino" (FURTADO, 1987)

Conforme demonstrou-se anteriormente a partir dos documentos e relatos levantados pela pesquisa, o encadeamento apresentado por Furtado apresenta alguns pontos incorretos. O processo já havia se iniciado antes de 1978, embora tenha sido neste ano que ele de fato caminhou com mais força. A análise pelas escolas do currículo proposto foi feita antes do Seminário "Desenho Industrial e Ensino". Furtado também comenta no plural sobre "novos currículos mínimos", como se houvesse mais versões, ou talvez uma versão para Desenho Industrial e outra para Comunicação Visual, sendo que este último não foi encontrado pela presente pesquisa.

A seguir, Furtado comenta sobre a Comissão Especial para Estudos do Currículo Mínimo de Desenho Industrial, que reformulara a pré-proposta anterior para que fosse amplamente discutida em 1979 no 10 ENDI. "A nova proposta foi enviada em janeiro de 1980 a todas as escolas e associaçóes para amplo debate e sugestôes, tendo a SESU então recebido integral apoio à proposta tal qual aprovada no I ENDI" (FURTADO, 1987). Estranha-se este novo encaminhamento comentado, bem como o apoio integral à proposta aprovada no $1^{\circ}$ ENDI. Já naquele momento comentou-se sobre a morosidade das discussóes no evento, e mesmo os pareceres anteriores das escolas sobre a proposta não foram unânimes entre si. É questionável que, caso tenha havido esta nova chance para alteraçóes do seu conteúdo, náo te- 
nham havido sugestóes neste sentido, ainda que o documento tenha sido aprovado em reuniáo representativa da categoria.

Furtado comenta, a seguir, sobre um relatório elaborado por Gustavo Amarante Bomfim, onde justifica a dupla habilitação para um único curso:

Particularmente o assunto foi considerado em um relatório elaborado pelo Prof. Gustavo Amarante Bonfim, Coordenador da Comissão Especial para Estudos do Currículo Minimo, para a SESu, no qual é mencionado que "o desenvolvimento do curso em duas habilitaçóes atendeu à tendência já existente nos cursos de Desenho Industrial, onde a habilitação, ainda que informal, é fato comum na escolha do tema dos projetos de formatura, quando os alunos optam por um tema em uma das duas áreas de concentração". Continua ainda o mencionado relatório dizendo que "...as habilitaçóes em Projeto do Produto ou Programação Visual visam na prática a possibilidade de uma maior aprofundamento em cada uma das duas áreas, permitindo ao aluno uma formação mais sólida, preparando-o para o mercado de trabalho, sem contudo impedir que o mesmo se habilite nas duas áreas se assim o desejar"

[...] "Em face do exposto, conclui-se que a proposta de curriculo mínimo para o curso de Desenho Industrial, aprovada no I ENDI, embora com pequenas modificaçóes a serem compatibilizadas pelos especialistas sugeridos na presente Informação, responde pelos anseios da área. Portanto, em condiçôes de ser encaminhado ao CFE para apreciação e posterior aprovação". (FURTADO, 1987)

Furtado comenta, ainda, sobre um terceiro relatório, com participação de Itiro Iida e Gustavo Amarante Bomfim, onde ambos se mostraram novamente favoráveis à publicação do Currículo Mínimo conforme tirado do $1^{\circ}$ ENDI, sem novas alteraçóes, pois

embora algumas instituiçôes tenham demonstrado vivo interesse, enviando sugestóes à proposta curricular em debate, essa foi aprovada na assembléia do I Encontro Nacional de Desenho Industrial, cuja representatividade não conhece paralelos na história do Desenho Industrial no Brasil. (IIDA \& BOMFIM, s.ld. apud FURTADO, 1987).

O relator finaliza seu parecer afirmando que nem as ementas das matérias, 
nem a introdução sugerida na minuta tirada do $1^{\circ}$ ENDI seriam incluídas na resolução final, mas que seu conteúdo poderia ser checado neste mesmo documento assinado por Furtado (FURTADO, 1987).

Não há comentários em seu relatório quanto à Comissão para Avaliação do Ensino Superior de Desenho Industrial de 1986, tampouco seu relatório. Também quanto aos documentos intermediários assinados por Bomfim e Iida não há referências de datas, para que se localize quando exatamente foram escritos, e qual o encadeamento temporal relativo aos demais eventos e grupos formados até meados dos anos 1980.

Quanto ao currículo em si, houveram pequenas modificaçóes nos nomes das matérias sugeridas no $1^{\circ}$ ENDI, conforme a Tabela 15.

PROPOSTA $1{ }^{\circ}$ ENDI

RESOLUÇÃO № 2/87

\section{MATÉRIAS BÁSICAS}

Matemática

Física Experimental

Meios de Representação Bidimensional

Meios de Representação Tridimensional

História da Arte e da Tecnologia

Economia

Noções de Economia

Antropologia, Sociologia e Psicologia

Ciências Sociais

Legislação e Normas

MATÉRIAS PARA HABILITAÇÃO EM PROJETO DE PRODUTO

Metodologia Visual

Teoria da Comunicação

Metodologia do Projeto

Ergonomia

Materiais industriais

Fabricação

Sistemas Mecânicos

Desenvolvimento do Projeto do Produto 


\section{MATÉRIAS PARA HABILITAÇÃO EM PROGRAMAÇÃO VISUAL}

Metodologia Visual

Teoria da Comunicação

Metodologia do Projeto

Ergonomia

Materiais, Fabricação e Processos Materiais e Processos Gráficos

Produção e Análise Gráfica

Produção e Análise da Imagem Sequenciada Produção e Análise da Imagem

Desenvolvimento do Projeto de Programação Visual Desenvolvimento do Projeto de

Comunicação Visual

Tabela 15: Comparativo entre a proposta de Currículo Mínimo aprovada no $1^{\circ}$ ENDI, e efetivamente publicada na Resolução $n^{\circ} 2 / 87$. Fonte: do autor.

Chama-se à atenção a mudança de nome de "Desenvolvimento do Projeto de Programação Visual” para “[...] de Comunicação Visual”. Estranha-se a troca, dado que a habilitação permanece como Programação Visual.

Quanto às ementas das matérias, existem algumas poucas diferenças quanto ao conteúdo da proposta do $1^{\circ}$ ENDI. Destaca-se na matéria "Meios de Representação Bidimensional”, a inclusão do conteúdo "[Desenho] de Expressão e de Modelo Vivo", que apareceu em versóes preliminares do currículo, mas que havia sido removido em sua versão final, inclusive por pedidos da Esdi, que identificava como uma prática das Belas Artes e não do Design (PORTINHO, 1979). As demais alterações são menores e não introduzem ou removem conteúdos da ementa.

Furtado não menciona nem explica tais diferenças, e nas versôes anteriores ao $1^{\circ}$ ENDI a que teve-se acesso não há uma versão que se assemelhe por completo à final publicada na resoluçáo no $2 / 87$. Estas mudanças, especulamos, talvez tenham sido feitas por alguma das comissóes comentadas por Furtado, ou por alguém que já conhecia outras discussóes feitas durante o processo de escrita do currículo. Ao certo não sabemos.

A publicação no Diário Oficial da União como resolução no 2/87 se deu em 22 de junho de 1987. Consta, ainda, que o currículo deveria entrar em vigência a partir do ano letivo de 1988. Para alunos matriculados antes de 1988, ficaram mantidas as exigências do currículo anterior, de 1969. 


\subsection{Reações da categoria à publicação}

Após a publicação do novo Currículo Mínimo em 1987, houve certa movimentação para discutir sua implementação, e também para avaliar possibilidades de atualização de seu conteúdo, já que tinham se passado oito anos desde sua formulação.

De fato, desde a escrita da proposta de Currículo Mínimo em 1979, tanto aspectos do ensino de design, quanto de organização de grupos profissionais e acadêmicos, e a própria dinâmica de ocupação do mercado mudaram até sua publicação em 1987. A categoria conseguiu dialogar sobre diversos temas ao longo dos encontros do ENDI, que serviu como importante fórum nacional e definidor de pautas, além dos eventos e encontros regionais e locais. Houve também um grande esforço pela melhor organização da categoria por meio das associações, não apenas estaduais, mas mesmo de alcance nacional - como o Conselho Nacional de Desenho Industrial -, mesmo que tal esforço seja questionado por pesquisadores quanto a sua efetividade (MORAES 2003a; MORAES 2003b; ROPELATO, 2008).

Além da organização interna da categoria, o próprio mercado de trabalho se modificara ao longo do período, desde a escrita da proposta de Currículo Mínimo em 1979.

A década de 1980 foi considerada uma 'década perdida' pelos economistas devido aos periodos de recessão, problemas em infraestrutura baixo desempenho econômico etc. Porém, mesmo com as dificuldades e as restriçóes de mercado, foi a década na qual: os designers tiveram referências para se verem como uma categoria profissional, cresceram o número e os tipos de instituiçóes no campo profissional, cresceu o número de escritórios, foi definida a nomenclatura da profissão, abriram-se frentes em novos campos de atuação, a academia se organizou, os estudantes iniciaram a organização de seu fórum e o mercado que havia disponi foi aos poucos sendo conquistado. Nâo se tratou, portanto, de uma 'década perdida' para o campo profissional do design, mesmo com o fim da ideia de entidades pré-sindicais (BRAGA, 2016, p. 323)

Braga afirma, ainda, que o "[...] crescimento do setor de prestação de serviços, principalmente no final dos anos 1980, aumentou o número de trabalhos para o seguimento de autônomos e escritórios de design, com predomínio da área gráfica" (BRAGA, 2016, p. 320). 
Com o crescimento do setor de serviços, acontece também uma maior segmentação das atividades, com diversas especializaçóes que o Currículo Mínimo proposto em 1979 não abarcava nem conceitualmente - já que procurava pelo designer generalista uma solução para o difícil mercado do período anterior - nem em termos de conteúdo de matérias, inclusive pelo início da inclusáo de programas CAD e ferramentas digitais na rotina de projeto do designer. Vale recordar a crítica que Bomfim fez em 1983 à aversão por especializaçôes que o campo cultivava no entendimento do profissional designer (BOMFIM, 1983).

London, em seu depoimento à pesquisa, recorda-se das mudanças do mercado deste período:

E aconteceu também um processo muito curioso. Antes disso todo mundo se encontrava em todas as concorrências. Porque o mercado era desse "tamanico". Então fosse produto, fosse gráfico, fosse sei-lá-o-quê, estavam lá sempre as mesmas vinte pessoas, participando das mesmas concorrências. Daqui a pouco começou a acontecer um processo muito curioso. Que os nichos começaram a se caracterizar, e você já não encontrava mais todo mundo. Você encontrava as pessoas que escolheram aquele nicho. Entendeu? Então,

é... é interessante porque foi fazendo com que as especialidades aparecerem, e as competências aparecessem, entendeu? Porque todo mundo passou a mergulhar mais fundo, claro. Se eu escolhi esse nicho, e meu cliente tá ali, tem uma fábrica, tem uma responsabilidade, então...(Entrevista London, 2017)

Braga enxerga nesse fenômeno da segmentação uma das causas da queda de atuação da Apdins-RJ, que naquele momento se tornara APDI-RJ:

A APDINS-RJ, nascida em tempos de acomodação de interesses de profissionais em condiçóes de trabalhos diferentes, de consenso de ideias sobre como ocupar o mercado restrito e o modo de atuar não especializado, se diluía em tempos de crescimento, diversificaçâo, segmentação e 'especializaçâo' do design na sociedade. A não continuidade da APDI-RJ e a inexistência de outra associação profissional no Rio de Janeiro até 1998 foram relacionadas, por alguns dos entrevistados, ao individualismo provocado pela desvalorização da açâo coletiva e política por parte da classe média. A competiçâo no mercado entre designers e o cenário político e econômico neoliberal do final dos anos 1980 seriam ingredientes para a busca pela 
consolidaçâo de carreiras e conquistas profissionais individuais (BRAGA, 2016, p. 321)

Seria natural, assim, que diante desse cenário tenham se levantado questionamentos à proposta curricular finalmente aprovada. Críticas já vinham sendo feitas anteriormente, mas a publicação da Resolução no 2/87 e a demanda por readequaçôes dos currículos das escolas tornaram a pauta mais premente.

5.4.1. Encontro de Docentes para Avaliação do Novo Curriculo Mínimo para o Curso de Desenho Industrial

Segundo Ropelato (2008), em 1987 acontece o $1^{\circ}$ Encontro de Docentes para Avaliação do Novo Currículo para o Curso de Desenho Industrial. No encontro, representantes dos cursos de Desenho Industrial das faculdades UFSM, Fuma, Faap, Faculdade da Cidade e UFPR, além do LDP/DI, assinaram um ofício solicitando "[...] uma dilatação do prazo de implantação do novo currículo para até dois anos e preferencialmente a suspensão da meta para melhor e mais ampla discussão pelos profissionais de Desenho Industrial e Comunicação Visual” (UNIVERSIDADE FEDERAL DO PARANÁ, 1987; apud ROPELATO, 2008). Tal solicitação, entretanto, não parece ter sido atendida.

\subsubsection{Workshop "O ensino de desenho industrial nos anos 1990"}

Em 1988 ocorre em Canasvieiras um importante Workshop sob a tutela do LDP/ DI, que já contava com Eduardo Barroso na parte administrativa, e Marcelo de Resende na coordenação técnica desde março de 1987. Em junho de 1988, Barroso envia por correspondências o convite ao evento, bem como a chamada de trabalhos em cima de temáticas pré-estabelecidas.

Com o objetivo de resgatar as discussóes sobre a problemática do ensino de Desenho Industrial e propor alternativas para a próxima década, o Laboratório de Desenho Industrial - LDI/SC em conjunto com a UFSC realizará nos dias 25 a 29 de junho/88 o workshop "O Ensino do Desenho Industrial nos Anos 90".

[...] Todas as discussóes e propostas serão agrupadas em 4 grandes linhas temáticas, a saber:

1 - O ensino de graduação de Desenho Industrial. 
2 - Formação, pós-graduação e atualização de docentes.

3 - Pesquisa e extensão

4- Informação, intercâmbio e difusão (BARROSO, 1988a)

O LPD/DI, que a seguir mudaria o nome para Laboratório Brasileiro de Desenho Industrial - LBDI, era além de um laboratório de desenvolvimento de projetos, também um importante centro de complementação formativa desde 1984, sua fundação. Situado dentro da UFSC e ligado à área de engenharia da universidade, propunha-se a ser um centro "transprofissional" (LEON, 2014, p. 75) com a oferta de diversos cursos de aperfeiçoamento, dentre os quais Metodologia experimental - desenho industrial, Estrutura e estética do produto, e Design de Máquinas Especiais, todos esses oferecidos enquanto Gui Bonsiepe era o coordenador do Laboratório.

Com a chegada de Barroso e Resende ao laboratório, foram feitas uma série mudanças de espaço e ampliação de equipe (LEON, 2013, p. 102). O primeiro curso dessa nova fase foram dois cursos de "Design para Saúde", montado a partir do diagnóstico de que não havia formação específica nem generalista para demandas desse assunto específico nas escolas de design brasileiras. Segundo Leon:

O fato de não existirem outros laboratórios em funcionamento no país levou os novos coordenadores a pensarem em termos nacionais, e não mais regionalmente. Já em 1989, o nome do laboratório foi mudado para Laboratório Brasileiro de Desenho Industrial. A ideia central era que o Laboratório se tornasse uma referência para as escolas brasileiras, por meio de cursos, seminários e convênios (LEON, 2013, p. 108)

O interesse de Barroso pela discussão do ensino de design permaneceu durante seus trabalhos no Laboratório, e a realização do workshop "O Ensino do Desenho Industrial nos anos 90" é sinal disso.

Dentre as sugestôes de temas para o workshop, Itiro Iida aprofundou alguns itens que mereceriam destaque, e incluiu discussões sobre o currículo mínimo (BARROSO, 1988a). Foram enviadas também uma série de perguntas às escolas (BARROSO, 1988b), que deveriam respondê-las e remetê-las de volta a Barroso, como subsídio às discussóes do workshop. A maioria delas eram perguntas de caráter prospectivo, para se especular qual seria o papel da escola numa série de temas 
dentro dos próximos dez anos.

É interessante observar que diversas das perguntas abordam temáticas já elaboradas em outros momentos, inclusive pela própria Comissão para Avaliação do Ensino Superior de Desenho Industrial, da qual Barroso fez parte. Embora não façam referência ao relatório final da comissão, entende-se que este serviu de base para o mesmo, e que tal relatório servia de pano de fundo para o evento. Um indício disso está na nota publicada no Informativo do LBDI, publicado em abril 1989, onde coloca-se:

"Inadequação curricular, distanciamento com a realidade industrial e social do pais, falta de mecanismos adequados de apoio ao ensino e formaçâo de docentes, foram alguns dos problemas levantados, em 1986, por uma comissão designada pelo Ministério da Educação para analisar a situação do ensino do Desenho Industrial nas universidades brasileiras. De lá para cá, pouca coisa mudou, segundo avaliação dos representantes das universidades. por isso, "O Ensino do Desenho Industrial dos Anos 90" retomando as discussóes travadas até aqui, fez uma profunda reflexão sobre a atual situação, propondo um conjunto de medidas que se implantadas, deveráo mudar os rumos da politica de ensino superior nesta área" (INFORMATIVO DO LBDI, n. 2 abril de 1989. p.06)

Outro ponto interessante é que na programação não constava uma importante questão que foi, ao final, definidora do seminário, que foi o debate sobre o nome da profissão. Ao final do workshop, tira-se a definição de mudança de nomenclatura da profissão, passando de Desenho Industrial para Design, assim como ambas habilitaçôes passariam a ser Design Gráfico e Design Industrial. Segundo Leon, "[a] proposta de mudar o nome da profissão foi acatada pouco tempo depois no $\mathrm{V}$ Encontro Nacional dos Desenhistas Industriais (ENDI)” (LEON, 2013, p. 116; BRAGA, 2016, p. 240).

\subsubsection{Carta de Canasvieiras}

O documento final que sintetiza os debates e definições do evento fora denominado "Carta de Canasvieiras", onde abordam-se cerca de 30 pontos que guiariam o campo ao longo dos próximos anos. A carta, redigida durante o evento nos dias 25 a 29 de junho de 1988, possui três versóes diferentes: a redigida logo após o evento, e que fora submetida a associaçóes, escolas e profissionais do campo; uma 
versão de meados de setembro do mesmo ano, contendo atualizaçóes a partir de comentários recebidos; e uma última versão distribuída em 1989 no jornal do LBDI, impressa em tamanho próximo a A2.

Como preâmbulo do Jornal à versão final da carta:

Apresentamos em sua integra o documento "Carta de Canasvieiras", produto conclusivo do workshop "O Ensino do Design nos Anos 90", organizado pelo Laboratório em julho do ano passado.

Nesta ocasião, reuniram-se pela primeira vez representantes de todas as escolas de design do Brasil, discutindo durante cinco dias temas que haviam sido objeto de prévia reflexão junto ao corpo docente e discente de cada uma das escolas (JORNAL DO LDP/ DI, 1989)

Na apresentação da carta:

Esta Carta de Canasvieiras, documento de abrangência nacional, deflagra o movimento que viabilizará pensamentos de açóes comprometidas com a mudança qualitativa do design brasileiro, conclamando a todos os docentes, profissionais e instituiçóes a se integrarem no esforço de criação e implementação da Associação Brasileira de Ensino do Design - ABED.

[...] Esta Carta pretende, também, alinhando 32 recomendaçôes elou proposiçóes, fornecer os indicadores para a correção da trajetória do ensino do design, possibilitando a preparação de profissionais cujo trabalho acontece para, e na sociedade do século XXI. (CARTA DE CANASVIEIRAS, 1989)

Logo o primeiro ponto refere-se à mudança de nomenclatura, que visa "[...] corrigir um erro histórico de tradução do termo 'design' para desenho, terminando-se assim uma longa série de equívocos e incompreensóes, que a falta de um nome claro e preciso à profissão sempre ocasionou" (CARTA DE CANASVIEIRAS, 1989). Ainda neste item, reafirma-se que tanto o termo Design, quanto os títulos anteriores de Desenho Industrial, Comunicação Visual, Desenho de Produto e Projeto de Produto são de uso exclusivo de cursos de $3^{\circ}$ grau. "Com isso, quer se evitar uma falsa habilitação ao $2^{\circ}$ grau, que poderia acarretar dúvidas quanto à qualificação profissional exigida para o desempenho destas funçôes" (CARTA DE CANASVIEIRAS, 1989). 
O segundo ponto trata da fundação da ABED - Associação Brasileira de Ensino de Design, idealizada em 1984 no 1º Encontro de Diretores das Escolas Superiores de Desenho Industrial do Brasil.

Outro ponto que se destaca para esta pesquisa é o item 7, onde recomenda-se que o $\mathrm{CFE}$ designe à $\mathrm{ABED}$ a reavaliação do Currículo Mínimo aprovado no ano anterior, e que tal reavaliação seja feita "[...] ao término de cada exercício letivo", ou seja, uma reavaliação constante, com um reestudo completo no ano de $1992^{10}$ (CARTA DE CANASVIEIRAS, 1989).

Há, a seguir, uma nova referência à Comissão Especial para Avaliação do Ensino Superior de Desenho Industrial, de 1986, reiterando seus apontamentos quanto à preponderância das disciplinas de projeto em todos os cursos de design do país.

No item 10 da Carta, em tema também abordado pela Comissão de 1986, recomenda-se que as escolas procurem a adoção de sistema seriado de ensino, em detrimento do sistema de créditos então adotados.

Os itens 11 a 15 referem-se ao trabalho de graduaçáo, onde recomenda-se a obrigatoriedade de um projeto de conclusão de curso - não se comenta sobre trabalhos teóricos. Tais trabalhos teriam um tema sugerido nacionalmente pela ABED, e deveriam preferencialmente ser avaliados por "[...] representantes de outras áreas do conhecimento e/ou do setor produtivo" (CARTA DE CANASVIEIRAS, 1989).

Em outro ponto também abordado pela Comissão de 1986, o item 20 recomenda que órgãos de fomento analisem toda a produção técnica e projetual de candidatos a bolsas, e não apenas sua produção científica, e que o mesmo seja considerado pelas universidades para a progressão de carreira de seus professores.

O fato de diversos dos pontos destacados na Carta serem concordantes com o relatório da Comissão Especial para Avaliação do Ensino Superior de Desenho Industrial, de 1986 é importante, pois se referenda pela categoria acadêmica algo que o grupo havia proposto por conta própria, ainda que com consultas a esse mesmo público. Mostra, ainda, que aquele relatório serviu, efetivamente, de base às discussôes do encontro.

10 Não há justificativa para a escolha do ano, talvez por ser quando completa cinco anos da publicação original em 1987. 


\subsection{A adoção do novo Currículo Mínimo pelas escolas}

A análise feita até aqui de parte do conteúdo da Carta de Canasvieiras procurou entender como a categoria enxergava, naquele evento, o papel do Currículo Mínimo que havia sido há pouco publicado. $O$ fato de haver uma menção explícita à avaliação anual do currículo por parte da ABEDI indica que a avaliação periódica e posterior aprovação a serem feitas pelo CFE seriam consideradas ineficientes ou insuficientes para as mudanças que o campo esperava passar na próxima década, e que uma reavaliação constante bem como carta branca para atualizaçóes seriam mais interessantes para o ensino de Design.

À parte da discussão, o Currículo Mínimo, ao final, encontrava-se publicado, e tornou-se obrigatória sua adoção a partir de 1988.

Ropelato recorda o Encontro de Docentes para Avaliação do Novo Currículo para o Curso de Desenho Industrial, quando se solicitou a prorrogação do prazo de implementação em dois anos (ROPELATO, 2008). Segundo o autor, "[o]s dois anos - pedidos pelos paranaenses e demais - transformaram-se em uma eternidade, e o currículo mínimo acabou sendo substituído sem muitas aplicações suas" (ROPELATO, 2008). Entretanto, não parece ter acontecido dessa forma em todos os cursos.

Temos informações de algumas das escolas que realizaram a atualização curricular, e não de forma superficial. Notadamente, a Esdi e a PUC-RJ realizaram sua implementação ainda no ano de 1987, para aplicação já em 1988.

A Esdi iniciou sua discussão de adequação ao novo Currículo Mínimo em 27 de agosto de 1987 (ATA DE REUNIÃO, 1987), em reunião com docentes e discentes. $\mathrm{O}$ primeiro ponto averiguado pelo grupo foi da possibilidade de formação nas duas habilitaçôes, Projeto de Produto e Programação Visual. Em reunião do dia 09 de setembro, decidiu-se pela possibilidade tanto de formação num prazo de quatro anos em apenas uma delas a ser escolhida após o segundo ano concluído, quanto à formação conjunta num prazo de cinco anos (ATA DE REUNIÃO, 09 de setembro de 1987). Enaltece-se nesta ata a rapidez dos trabalhos e a concordância geral dos presentes quanto à nova estrutura curricular.

A PUC-RJ por sua vez, segundo entrevista com a Profa. Rita Maria de Souza Couto, iniciou as discussões para a reformulação do seu próprio currículo logo após a publicação do novo Currículo Mínimo em junho de 1987, entrando em vigor em 1988 (COUTO, 2017). Couto ressalta que o Currículo Mínimo novo, apesar de comemorado - dado que substituía o outro currículo de 1969, com qua- 
se vinte anos -, já era reconhecido como defasado, impedindo uma série de inovaçóes que a escola gostaria de realizar, as quais foram inseridas na grade como disciplinas eletivas.

Para os alunos que já se encontravam na instituição, que haviam cursado uma série de disciplinas, continuariam com as mesmas disciplinas do currículo anterior, com algumas poucas correspondências com as disciplinas novas, enquanto alunos recém-ingressos já se adequariam ao currículo novo. Couto ressaltou como interessante o fato de que, apesar de o novo Currículo Mínimo já estar defasado em sua publicação, fora difícil fazer as devidas correspondências para as disciplinas novas, dado que as diferenças para o anterior eram muito grandes. Reafirma com isso o quanto estava defasado o currículo anterior de 1969, que embasou o curso que ela mesma cursou entre 1984 e 1988.

Além destes, encontramos documentos que citam a adequação do curso de Desenho Industrial da Faculdade Belas Artes de São Paulo, criado nos anos 1980.

Novos cursos, por outro lado, já teriam que ser criados dentro dos novos moldes do Currículo Mínimo publicado, e desde o final dos anos 1980 até meados dos anos 1990, período de vigência deste Currículo Mínimo, aconteceu um crescimento vertiginoso da quantidade de cursos superiores no Brasil. É bastante improvável que tal crescimento se desse sem o cumprimento da Resolução no 02/87.

\subsection{Epílogo: do Currículo Mínimo às Diretrizes Curriculares Nacionais}

Com a nova constituição brasileira de 1988, uma nova LDB é publicada em 1996. A Lei

9.394 extingue os Currículos Mínimos, e um novo paradigma educacional entra em vigor, baseado em habilidades e competências, muito diferente do sistema anterior que via nos conteúdos em sí a base da educação.

Se o processo de escrita do Currículo Mínimo de 1987 já mostrou-se mais democrático do que a versão de 1969, pode-se dizer o mesmo da escrita das Diretrizes Curriculares Nacionais de 2004, quando comparada ao Currículo Mínimo de 1987. Houveram diversos fóruns de discussão encabeçados por uma comissão permanente de designers, que conseguiram, enfim, sua autonomia dentro do Conselho Federal de Educação do MEC.

A Comissão de Especialistas de Ensino de Design, ou CEEDesign, foi uma conquista da categoria. Antes, o Design estava ligado à CEEArtes, que responsabi- 
lizava-se por discussões do ensino de Artes Plásticas, Música, Dança, Teatro, Educação Artística, e do próprio Design.

Este novo capítulo para a história do ensino de design constitui uma nova pesquisa, com novas frentes e diversas questóes abrem-se para o papel de como o Currículo Mínimo interferiu nas ideias e mentalidades deste novo paradigma.

Há, de início, importante material no livro de Rita Couto, o mesmo que inspirou incialmente esta pesquisa sobre os Currículos Mínimos. Consiste, também, de uma pesquisa com outro caráter, dado que neste momento o uso de correio eletrônico já era normal, tornando, quem sabe, o acesso a discussóes e debates mais fácil, e possibilitando mais aprofundadas análises sobre o que estava em disputa no campo neste novo momento. 